\title{
AN ANALYSIS OF CODE SWITCHING USED IN PHOTO CAPTION BY FACEBOOK USER
}

\author{
Ovella Melvia $^{1}$, Yuliyanti ${ }^{2}$, Lilis Suryani ${ }^{3}$ \\ ${ }^{1}$ IKIP Siliwangi \\ ${ }^{2}$ IKIP Siliwangi \\ ${ }^{3}$ IKIP Siliwangi \\ ${ }^{1}$ ovellamelvia1616@gmail.com, ${ }^{2}$ yuliyanti011115@gmail.com, ${ }^{3}$ suryani.lies@gmail.com
}

\begin{abstract}
The aims of this research are to identify the types of the code switching appeared on Facebook for the reason phenomena and to investigate the reasons that affect the occurrence of code switching in Facebook. This research uses qualitative method with Hoffman (1991) and Saville-Troike (1986) theories. The data were collected from photos caption and status on Facebook during twenty days from 1st January 2018 to 20th January 2018, that were posted by 90 users who were followed by the researchers on Facebook. 120 data have found on status and photo caption facebok. The result of this research shows that there are three types of code switching on Facebook, namely Inter-sentential switching with 54 data, Intra-sentential switching with 50 data, and Emblematic switching with 16 data. Besides that there are five reasons which influence the use of code switching on Facebook, namely talking about particular topic with 39 cases found, quoting somebody else with 13 cases found, being emphatic about something (express solidarity) with 45 cases found, Interjection (inserting sentence fillers or sentence connectors) with 10 cases found, and real lexical need with 13 cases found. The dominant reasons which influence the use of code switching on Facebook are being emphatic about something (express solidarity) with 45 cases.
\end{abstract}

Keywords: Code Switching, Facebook, Sociolinguistic

\section{INTRODUCTION}

Language is one of the important things for humans to communicate in society, without language the people can not interact with each other. In linguistic, it is known as sociolinguistic. According to Holmes (2001) as cited in Piantari, Muhatta, \& Fitriani (2011), sociolinguistics is a science that examines the relationship between language and society. Sociolinguistics concentrates on the correlation between social factors and linguistic variations. Sociolinguistics basically does not focus on the structure of a language, but rather focuses on how the language is used in its social and cultural context. One of the concentrations in sociolinguistics is code switching.

People that used more than one language in a conversation is the common phenomenon in this recent years usually come from bilingual people. Gumperz (2003) as cited in (Piantari et al., 2011) state "bilingualism is primarily a linguistic term, referring to the fact that linguists have discovered significant alternations (pronunciation, word structure and grammar) in studying the verbal behavior of a particular population". It means a bilingual people should mastery two language perfectly.

The sociolinguists or people who study about language should know about "code and switching". Stockwell (2002) as cited in (Yuliana, Luziana, \& Sarwendah, 2016) defines "A code is a symbol of nationalism that is used by people to talk or communicate in a particular 
language a dialect, a register, an accent or a style on different occasions and purposes". While "switch is the process of selecting or changing linguistic elements for the sake of effectiveness in communication" (Ewert 2010) as cited in (Fathimah, 2016). From definition about code and switching above, code switching is a process selecting a language that used by human to make the effectiveness in communication. In addition Sumarsih, Siregar, Bahri, \& Sanjaya (2014) state that code switching is a combination between 2 language or more based on two distinct grammatical system across sentence boundaries within the same speech event.

Basically, Indonesian people can also speak in two or more languages. They master the local language, the Indonesian language as the national language, and even the foreign language. Speakers often use two languages that are directly mastered, spontaneously, and unintentionally. This phenomenon can be explained as a code switching event that can not only be found in verbal communication, but can also be found easily in non-verbal communication as in social media.

A social media is an online platform which people use to build social networks with other people who share similar personal or career interests, activities, backgrounds or real-life connections (Akram \& Kumar, 2018). In addition, many studies has been carried out on students usage of social media, its impact on their social behaviour, education, academic performance as well as the positive and negative impact, the factors that influence the usage, ethical usage and many more (Chukwuere \& Chukwuere, 2017). Social media is also the media online that supports social interaction by engaging anyone interested to participate with member contributions and feedback openly, members comments, and share information in a fast and unlimited time. One of social media that is widely used today is Facebook.

In Facebook, users can create a phrase called "status" on the facebook wall, upload virtual files like photo caption. Facebook designed by Mark Elliot Zuckerberg, can be accessed through smartphone or gadget based on android very easily. For those who love the visual world like photography, facebook is the place to be right to express and publish the work. Based on Liputan6.com, Jakarta, Indonesia ranked 4th in the world with the most active Facebook users. This is revealed from research reports We Are Social and Hootsuite are released on LinkedIn, Friday (21/4/2017). Facebook claimed increasingly dominate the world of social media in the world. Until now, the social media giant owned by Mark Zuckerberg has already pocketed 1.968 billion active users. As many as 89 percent of them access via smartphone and 61 percent access Facebook every day. Once broken down by gender, 44 percent of users are women and 56 percent are men. With such numbers of users, code switching is easy and often found in Facebook and is usually used by bilingual people in writing captions for photos, they upload to facebook.

\section{Code Switching}

Hoffman (1991) and Saville-Troike (1986) show three forms of code switching based on the sociolinguistic sphere in which the language lies. The three forms of code switching are Intersentential switching, Intra-sentential switching, and Emblematic Switching. Each of these forms will be explained below:

\section{1.inter-sentential Switching}

This form of code switching occurs between clauses or sentence boundaries, where each clause or sentence is in one language or another. 


\section{Intra-sentential Switching}

This form of code switching occurs in a phrase, clause or sentence boundary.

\section{Emblematic Switching}

In this type of code switching, the specified tags, exclamation and phrase sets in one language entered into the speech are expressed in another.

When code switching occurs, the motivation or reason for the speaker to switch code is an important consideration in the process. According to Hoffman (1991) and Saville-Troike (1986), there are a number of reasons that affect speakers to change code:

\section{Revealing Specific Topics.}

Speakers sometimes choose to switch code because to reveal a particular topic.

\section{Quoting Others.}

The speaker switches the code to quote the proverb or phrase of famous figures from various sources and quoted in full in the original language.

\section{Reinforce Something (Expressing Solidarity).}

When someone who speaks a language that is not his native language and suddenly wants to confirm something, he either intentionally or unintentionally, will do the code change to confirm his words.

\section{Interjection (Include Sentence Filler or Sentence Liaison).}

The word appeal is the words or phrases put into the sentence to convey surprises, strong emotions, or to get attention.

\section{Lexical Need}

When an Indonesian-English bilingual speaker has a word lacking in English, it will be easier to say it in Indonesian.

From the reasons above, the researchers can conclude that speakers do the code switching because they want to make a clear explanation to the listener. The study was conducted with the aim of identifying and classifying forms of code switching in Facebook and for analyzing and explaining the reason for the occurrence of code switching in Facebook.

\section{METHOD}

In this research, the researchers used qualitative method. As stated by Perry (2005) cited in Dewi, Hernawan and Apsari (2019) that qualitative research is characterized by the verbal description of its data. In collecting the data, the researchers took status and photo caption from 90 facebook users with some stages as follow:

\section{Preparation}

The researchers looked for some journals on sociolinguistics that contained theories on the topic of this research, especially journal that explain much about code switching, and educational articles writing about code switching. Then the researchers access the social media Facebook through the application Facebook is downloaded through the Play Store and logged in with an account with the username is @ovellamlv.

\section{Data Collection}

Data collected from post status, and photo captions, on Facebook since $1^{\text {st }}$ January 2018 to $20^{\text {th }}$ January 2018 posted 358 Facebook users who have followed. The researchers explored each of the following accounts to retrieve data in status and caption. From this data collection process, the researchers found 90 users like @satria musa, @rahmat selamet, @jerry lee 
@yogi, @sidratul muntaha, @feby lestarina ZA,@anur gusnini, @fadhel muhammd fadhel @yorgi octdlyr, @rahmad handi shaputra, @Crizky, who on their account did a lot of code switching in writing caption or status. The researchers limit the data collected by simply retrieving data, containing the code switching element in English-Indonesian or in IndonesianEnglish. Then the researchers captured the status and photo caption on each data found by the researchers.

After the researchers found 120 data containing elements of code switching on photo caption and status on Facebook, the researchers directly move the data into the data collection folder that has been prepared in the computer media so that the data used can be easily and quickly accessed when identifying, classification, and analysis on the data already obtained.

\section{Data Analysis}

At this stage, 120 data have been obtained by the researchers, the data in the form of photo captions and status, in Facebook that contains code switching in it, the data identified and classified in a way, first researchers create a draft in Microsoft Word, then the researchers reread the data that has been collected and copy the data into drafts that have been made, based on the types of code switching according to Hoffman (1991) which was described earlier by the researchers in introduction. The data used by the researchers amounted to 120 data or $65.9 \%$ which is 61 data code switching Indonesian into English and 59 data code switching in English to Indonesian. Data selected based on the initial classification performed by the researchers, where researchers only take one or two of some data that identically have similarities with other data. Of the 120 data the researchers also conducted an analysis of the reasons that affect the occurrence of the code switching on the status and photo caption in Facebook based on the interpretation of the researchers only according to the theory of Hoffman (1991) and SavilleTroike (1986) which has also been described previously by the researchers in introduction.

\section{RESULTS AND DISCUSSION}

\section{Results}

The result of this research, there are 120 data found by the researchers that include types of code switching they are inter-sentential switching with 54 data, intra-sentential switching with 50 data, and emblematic switching with 16 data, the researchers also found the reasons which influences the user to code switching they are talking about particular topic with 39 cases, quoting somebody else with 13 cases, being simphatic about something with 45 cases, interjection with 10 cases, and real lexical need with 13 cases.

\section{The forms of code switching in Facebook}

The researchers classify the forms of code switching to the status and photo captions in Facebook using the theory of Hoffman (1991) that divides the forms of code switching based on the scope where the language is located into three namely, Inter-sentential Switching, Intrasentential Switching, and Emblematic switching.

\section{a. Code switching in Inter-sentential Switching}

The following data collection in the form of caption photos and status in Facebook included in the code switching that occurs between sentences with the number of 28 data code switching in 
the Indonesian to English and 26 data code switching in English to Indonesian. The reason why the data below is categorized as Inter-sentential Switching is because the code switching in the data set below appears in the form of a phrase or clause after the sentence limit. Code Switching of Inter-sentential in Indonesian to English, namely:

"Tak ada yang tiada, semuanya disini bisa diakal-akali, just for fun."

(photo caption by @ Crizky date $7^{\text {th }}$ January, 2018)

Code switching of Inter-sentential in the English to Indonesian, namely :

"Fb reminds me about the accident. Alhamdulillah ...Allah maha kaya, maha berkehendak, maha tahu segalanya."

(status by @Anur Gusnini date $8^{\text {th }}$ January, 2018)

\section{b. Code switching in Intra- sentential switching}

The following is a collection of data in the form of photo caption and status in Facebook included in the code switching that occurs in intra-sentential with the amount of 26 data code switching in the Indonesian into English and 24 data code switching in English to Indonesian. The reason why the data below is categorized as code switching that occurs in Intra-sentential Switching is because the code switching in the data set below appears in phrase or clause form within the sentence boundary.

The code switching that occur in Intra-sentential Switching in Indonesian to English, namely:

"Dari beberapa bibit aku tanam hanya satu yang hidup, pingin secepatnya sun flower keluar dan tersenyum met pagi all."

(photo caption by @ rahmat selamet date $7^{\text {th }}$ January, 2018)

The code switching that occur in Intra-sentential Switching in the English to Indonesian, namely:

\footnotetext{
"Walk in interview hari pertama utk Mall Living World Pekan Baru...ruaaaarrr biasaa ..."

(photo caption by @ Jerry Lee date $8^{\text {th }}$ January, 2018)
}

\section{c. Code switching of Symbolic Code (Emblematic Switching)}

The following is a collection of data in the form of photo caption and status within Facebook included in the switching of symbolic code with the amount of 6 data code switching in the Indonesian to English and 11 code switching in English to Indonesian. The reason why the data below is categorized as symbolic override (Emblematic Switching) is that the code switching in the data set below appears in the form of a particular quote, tag, and phrase set in the Indonesian language which is inserted into English or vice versa. Switching of symbolic code (Emblematic Switching) in Indonesian to English, namely: better!"

"Sekarang usia mu genap 22 tahun, happy birthday my friends get older get

(status by @ Fadhillah Hidayatul E date $3^{\text {th }}$ January, 2018)

Code switching in Emblematic Switching in English to Indonesia, namely: 
"Open order! spaghetti mercon, pasta makaroni, pisang cokju, otak" mercon dan ceker merconnya, rasa dijamin endness harga gabikin jebol kantong, minat ?wa:08961701556"

(caption photon by @Yogi date $8^{\text {th }}$ January, 2018)

\section{Reasons that affect the occurrence of code switching in Facebook}

In explaining the reason for influencing the occurrence of code switching in Facebook, the researchers describes the cause of the code switching in photo caption or status in Facebook uses the theory of Hoffman (1991) on the reasons that affect the occurrence of code switching in detail as follows :

\section{a. Revealing Specific Topics}

Speakers sometimes choose to switch code because to talk about a particular topic. It can be seen in the following caption:

@ rahmad handi saputra This is my mother $;:) ;$

Jadi gini, ntah aku yang cepat tua atau ibuku yang awet muda, pasti banyak yang salah sangka kan?

(caption photon by @rahmad handi saputra date $7^{\text {th }}$ January, 2018)

In his caption, @ rahmad handi saputra expressed his pride in his second language of English by saying "this is my mother" and then switching the code into his first language to convey about his aging mother.

\section{b. Quoting Others}

Speakers switch code to quote the proverb or phrase of famous figures. It can be seen in the following caption:

@ yopikurniawan : “Pekerjaan paling menyenangkan di dunia adalah hobi yang dibayar."Ridwan Kamil. Fitting time with the fierce one and only @ whulandary before photoshoot for @ artikawhulandary beauty camp, I really love my job $<3<3<3$ "

(photo caption by @ yopikurniawan date $6^{\text {th }}$ January 2018 )

Through this caption, it is clear that the speaker is @ yopikurniawan quoting a sentence already mentioned by Ridwan Kamil earlier in the language used by Ridwan Kamil then that is the Indonesian. Then @yopikurniawan did the code switching to convey his personal message describes his activities relating to the quotes he uses, with using English.

\section{c. Reinforcing Something (Expressing Solidarity)}

When someone speaks in a language that is not a language his mother and suddenly he wants to affirm something, he either intentionally or unintentionally, will switch from second language to first language or vice versa. That matter can be seen in the following caption:

@ Yorgi Octdlyr: "wkwkwk minta di follow, udah di follow malah di unfollow, yaudah delete lagi! Artist juga ndag bung haha."

(photo caption by @Yorgi Octdlyr date $7^{\text {th }}$ January 2018)

In this caption, it is clear that @ Yogi Octdlyr is switching code to reinforce his statement about his instagram account, this statement is reinforced by the words "yaudah di delete again" 


\section{d. Interjection (Include Sentence Filler or Sentence License)}

The word appeal is the words or phrases put into the sentence to convey surprises, strong emotions, or to get attention. It can be seen in the following caption:

@Feby Lestarina ZA : “ Real pict! Ready dirumah Clutch untuk kepestanya bunsay @) Putih(aligator embossed clutch) Hitam (velvet twisted knot square clutch) Minat? Silahkan inbox aja ya (;)"

(photo caption by @Feby Lestarina ZA date $8^{\text {th }}$ January 2018 )

In her caption, Facebook account @Feby Lestarina ZA convey a strong emotion of the authenticity of photos on her online shop, first convey "real pict"at the beginning of the sentence.

\section{e. Lexical Needs}

When an Indonesian-English bilingual speaker has a word lacking in English, it will be easier to say it in Indonesian. On the contrary, when he has a word that is lacking in Indonesia, he will use the term in English. If he keep using the Indonesian then means it will be vague, and its meaning is not right. It can seen in the following status:

@ satria musa : "happy birthday David Silva sipenyihir lapangan hijau...long life and success terus main buat city".

$$
\text { (status by @ satria musa date } 10^{\text {th }} \text { January } 2018 \text { ) }
$$

In that status, the Facebook account @ satria musa do the code switching to mention the actual lexical form of the name of a ball club "city".

Based on the result, the researchers concluded that, there were three code switching namely, inter-sentential switching, intra-sentential switching, and symbolic code (emblematic switching), beside that, there were five reasons that affect the occurrence of code switching in facebook namely, revealing specific topics, quoting others, reinforcing something, interjection, and lexical needs. It is related to theory of Hoffman (1991) who says code switching is a process selecting or changing a language that used by people to make the effectiveness in communication. It supported by Piantari et al (2011) who be a researcher before code switching in facebook used to give expression of emotion and feel, to convey the meaning appropriately, to emphasize the certain meaning, and also to uncover the identity.

\section{CONCLUSION}

The researchers found 120 cases of code switching that occurred within writing photo caption or status in Facebook. 120 cases of code switching it happens in photo caption and status by 90 users from 358 Facebook users who have been followed by the researchers. 120 cases later classified by shape and finding 54 cases of code switching inter-sentential switching, 50 cases of code switching referred to in Intra-sentential Switching, and 16 cases of code switching referred to in Emblematic Switching.

In the meantime, for reasons that affect the occurrence of code switching in Facebook, the researchers managed to analyze 120 cases of code switching that has been classified form first. The researchers found 39 cases of code switching that occurs for reasons to talk about a particular topic, 13 cases over the code occur for the reason of quoting others, 45 cases over the code occur to reinforce something (express solidarity), 10 cases overheading occurs for 
Interjection (inserting filler or linking sentence) 13 cases of code switching occurs due to lexical needs.

\section{ACKNOWLEDGMENTS}

Alhamdulillahirabbil 'alamiin, praise to Allah S.W.T who has enabled the researchers to finish this article. Peace and salutations are always for Rasullulah SAW. During completing the article, the researchers obtained a lot of help, suggestions, and motivations from many people. For the reason, the researcher would like to express her graduated to:

1. Lilis Suryani, M.Pd as the first advisor for their guidance and help to finish this article

2. Her beloved parents, sisters, and brother who always give their prays, materials, and motivations.

3. All her beloved friends who always care, give support, help and contribution for her, may we all get success.

\section{REFERENCES}

Akram, W., \& Kumar, R. (2018). A Study on Positive and Negative Effects of Social Media on Society. International Journal of Computer Sciences and Engineering, 5(10), 351-354.

Chukwuere, J. E., \& Chukwuere, P. C. (2017). the Impact of Social Media on Social Lifestyle: a Case Study of University Female Students. Gender \& Behaviour, (April 2018).

Dewi, M. W., Hernawan, K. F., \& Apsari, Y. (2019). Thematic Progression in Students'descriptive Texts. Project (Professional Journal Of English Education), 2(2), 227-233.

Fathimah, D. N. (2016). Why Is There Code Switching in Efl Classroom? : a Case Study in a Vocational School in Cimahi West-Java. Jurnal Pendidikan Bahasa Dan Sastra, 16(1), 70.

Hoffman, C. (1991). An Introduction to Bilingualism. New York: Longman.

Kalangit, R. F. (2016). No Titleпрроo. Alih Kode Dalam Instagram, 2016.

Piantari, L. L., Muhatta, Z., \& Fitriani, D. A. (2011). Alih Kode (Code-Switching ) Pada Status Jejaring Sosial Facebook Mahasiswa. 1(1), 12-18.

Saville-Troike. (1986). The Ethnography of Communication: An Introduction. Oxford: Basil Blackwell publisher.

Sumarsih, Siregar, M., Bahri, S., \& Sanjaya, D. (2014). Code Switching and Code Mixing in Indonesia: Study in Sociolinguistics? English Language and Literature Studies, 4(1), 7792.

Yuliana, N., Luziana, A. R., \& Sarwendah, P. (2016). Code-Mixing and Code-Switching of Indonesian Celebrities: A Comparative Study. Lingua Cultura, 9(1), 47. 